\title{
Effects of Cadmium Exposure on Tissues of Carassius auratus
}

\author{
Myung Ja Shin, O Chang Kwon, Jong Eun Lee and Eul Won Seo*
}

Department of Biological Science, Andong National University, Andong 760-749, Korea

Received July 7, 2010 /Accepted September 16, 2010

\begin{abstract}
The present study aimed to investigate the level of accumulated heavy metal in various tissues of Carassius auratus after exposure to Cadmium (Cd), histologically and physiologically. After treating $C$. auratus with $\mathrm{Cd}$, the accumulated $\mathrm{Cd}$ in gill tissues was detected to be of the highest content, and showed the lowest content in integument tissues. Also, $\mathrm{Cd}$ content increased in a time dependent manner and showed the highest accumulation in the tissues exposed for 20 days. Antioxidant enzyme activities showedhigher activity in the gill and integument than in the kidney and liver tissues. In the case of SOD, antioxidation activity of SOD in all Cd exposed tissues was higher than in unexposed tissues. The activities of SOD and CAT also became higher after Cd exposure. Gill tissues exposed to $\mathrm{Cd}$ showed an increased number of mucous cells between lamella in a time dependent manner. In addition, the gills showed morphological changes such as edema, exfoliation of epithelial cells, and fusion of the secondary lamellae. Also, exposure to Cd for 20 days had an effect on gill tissues, causing membrane damage in the mitochondria and nucleus. In kidney tissues, atrophied glomerulus was observed, and the empty space in Bowman's capsule was wider.
\end{abstract}

Key words : Cadmium, antioxidant enzyme, heavy metal, Carassius auratus

\section{서 론}

산업의 발달로 중금속은 여러 가지 화학물질의 합성에 다양 하게 이용되고 있으나 한편으로는 환경오염물질의 주요인자 로서 생태계에 있어서 생물학적 먹이사슬을 통해 여러 가지 급·만성의 독성 영향을 미치고 있다. 특히 환경오염물질로서 관심이 높은 카드뮴(cadmium, Cd)은 매우 유독한 유해 중금 속으로서 미량일지라도 생체 내에 침입하게 되면 생체의 혈장 단백질과 결합하여 간장, 신장, 고환, 근육 및 골격 등 여러 조직에 축적되고 생리적 기능장애를 유발하는 물질로 알려져 있다[7,10]. 또한 수계로 유입된 카드뮴은 동물의 조직에 지속 적으로 축적되고, 축적된 카드뮴의 독성은 노출되는 양과 형 태[7], 체내유입경로[14]에 따라 다르게 나타나는데, 신장 기 능, 중추 신경계, 골변화증, 근육통, 고혈압, 호흡곤란 등이 유 발되는 것으로 보고되고 있다[7]. 특히 어류의 경우, 미량의 카드뮴에 노출될 경우에도 조직 손상, 척추 변형, 호흡기 변화 등 치사에까지 이르게 된다[22]. 그러나 지금까지의 생체 내 $\mathrm{Cd}$ 축적에 대한 연구는 주로 실험동물을 이용한 실험적 연구 가 대부분일 뿐 수중에서의 어류를 이용한 실험적 연구는 많 지 않다. 또한 어류에 대한 중금속 축적 연구는 자연 생태계에 서의 어류를 채집하여 중금속 농도를 측정한 실험이 대부분이 어서 이들이 서식하는 생활환경과 물의 오염상태에 따라 측정 치에 차이가 있을 수 있어 사실상 특정 중금속에 어류가 노출

\section{*Corresponding author}

Tel : +82-54-820-5462, Fax : +82-54-820-7705

E-mail : ewseo@andong.ac.kr
되었을 때 어느 정도 축적되는지, 시간 경과에 따른 축적변화 는 어떠한 경향인지를 알아내기가 어렵다[19].

어류의 생체 내 중금속 축적이나 독성실험에는 수중 생태계 의 제반 특성과 어류의 종류에 따라 차이가 있으나 어류에 대한 독성시험법에 의하면 송사리, 붕어, 잉어, 금붕어 및 미꾸 라지 등을 공시어로 지정하고 있다. 따라서 잉어목, 잉어과에 속하는 붕어(Carassius auratus)는 한국, 중국 및 일본 등 아시아 권에 널리 분포하고 개체수도 풍부한 대표적인 담수어종이며, 실험실에서 순화가 잘 될 뿐만 아니라 채집에도 용이한 점이 있기 때문에 생물검정시험에 적합한 재료로 활용되고 있다[5]. 또한 선진국에서는 환경오염에 따른 수생생태계의 변화를 파 악하고자 이화학적 수질분석만을 이용한 수질관리에서 벗어 나 생물학적 감시망을 구축하였고, 이를 바탕으로 악화된 수 환경을 보전 및 복원하고자 꾸준한 생물모니터링 및 수생생물 의 생태적 특성 및 생리·생화학적 연구를 실시하고 있다[21]. 더불어 $\mathrm{Kim}$ 등[15]은 안동호와 임하호에 서식하고 있는 붕어 의 조직에 축적되어 있는 중금속의 양을 측정한 결과 안동호 에 서식하는 붕어의 조직에서 $\mathrm{Cd}, \mathrm{Cr}, \mathrm{Cu}$ 및 $\mathrm{As}$ 의 함량이 임하 호에 서식하는 붕어에서 보다 큰 것으로 조사되었지만 이러한 중금속이 어체에 미치는 형태 생리적 영향에 관해서는 거의 조사된 바가 없다.

따라서 본 연구에서는 안동호와 임하호에 서식하는 붕어에 서 조직 내 함량이 높으며, 안동호와 임하호 간의 함량차이가 컸던 $\mathrm{Cd}$ 을 대상으로 붕어를 $\mathrm{Cd}$ 에 노출시킨 후 각 조직에 축적 된 $\mathrm{Cd}$ 양과 항산화효소 활성을 통해 생리적인 변화 및 아가미 와 신장 조직에서의 미세구조 변화를 조사하였다. 


\section{재료 및 방법}

\section{실험 재료 및 노출 실험}

본 실험에 사용한 붕어(Carassius auratus)는 경북 의성군 비 안면에 위치한 약수 양어장에서 사육한 것으로 7일간 순치과 정을 거친 후 체장 $6.5 \pm 0.5 \mathrm{~cm}$, 무게 $3.5 \pm 1.1 \mathrm{~g}$ 인 건강한 개체만 을 선별하여 실험에 사용하였다. 실험은 $30 \times 60 \times 45 \mathrm{~cm}$ 크기의 수조에 각 10 마리씩 분배하였고, $\mathrm{Cd}$ 의 농도는 $\mathrm{CdCl}_{2}$ 로 표준액 을 제조한 후 농도에 따라 희석하여 사용하였다. 수조의 수온 은 $18 \sim 20^{\circ} \mathrm{C}$ 를 유지하여 96 시간 동안 실시하였으며 반수치사 농도는(50\% lethal concentration) 96시간에서 APHA [2]의 probit 값으로 구하였다. $\mathrm{Cd}$ 에 대한 $96 \mathrm{hr}-\mathrm{LC}_{50}$ 의 값이 0.564 $\mathrm{mg} / 1$ 로 나타나 중금속 노출농도는 급성실험을 통해 구한 96 $\mathrm{hr}-\mathrm{LC}_{50}$ 농도를 고려하여 $\mathrm{Cd} 0.3 \mathrm{mg} / \mathrm{l}$ 농도로 결정하였다(Fig. 1). 또한 노출기간은 5 일, 10 일 및 20 일 간격으로 설정하였고, 각 실험구당 70 마리씩 사용하였다. 대조군은 $0.3 \mathrm{mg} / 1$ 의 $\mathrm{Cd}$ 에 노출 실험 전 0 일을 대조군으로 하여 노출기간에 따른 실험군 과 비교하였다.

\section{조직 내 $\mathrm{Cd}$ 의 함량 측정}

붕어의 아가미, 빼, 근육 조직의 표면에 부착된 미세입자 및 이물질은 초음파세척기(5210, Branson, USA)를 이용하여 최대한 제거하였다. 미세입자와 이물질을 제거한 조직은 액체 질소로 처리하여 재차 냉동건조기에서 완전히 건조 후 건조중 량을 측정하였다. 각 조직 내 $\mathrm{Cd}$ 의 함량을 측정하기 위해 전처 리는 초단파 용해장치(Ethos Plus, Mileston, USA)를 이용하 였다. 전처리된 조직 내 $\mathrm{Cd}$ 의 함량은 유도결합 플라즈마 질량 분석기(Elan DRC-e, Perkin Elmer, USA)를 이용하여 측정하 였다.

\section{항산화효소 활성 측정}

\section{시료 추출}

붕어의 아가미, 신장, 간, 근육 조직을 적출하여 $100 \mathrm{mM}$ phosphate buffer (pH 7.2)에 혈액 및 기타 이물질 등을 세척한 후 조직의 무게를 측정하였다. 무게를 측정한 시료는 homogenation buffer (5 mM tris, $38 \mathrm{mM}$ glycine, $\mathrm{pH}$ 8.4)에서 완전히 균질화 시킨 후 시료는 $13,000 \mathrm{rpm}, 4^{\circ} \mathrm{C}$ 에서 10 분간 원심 분리 하여 지질층을 제외한 상등액만을 모아 $-70^{\circ} \mathrm{C}$ 에 보관하였다.

\section{Superoxide dismutase (SOD)}

$\mathrm{SOD}$ 활성은 $50 \mathrm{mM}$ potassium phosphate buffer (pH 7.8), $0.1 \mathrm{M}$ cytochrome $\mathrm{C}, 50 \mathrm{mM}$ xanthine, $0.1 \mathrm{mM}$ EDTA 및 효소액이 포함된 용액을 $25^{\circ} \mathrm{C}$ 에서 예치한 다음 xanthine oxidase를 첨가하여 반응을 개시하였다[17]. 효소의 활성은 550 $\mathrm{nm}$ 에서 10 초 단위로 150 초간 흡광도를 측정하였고, xanthine oxidase 첨가량은 효소액을 함유하지 않은 반응액의 흡광도

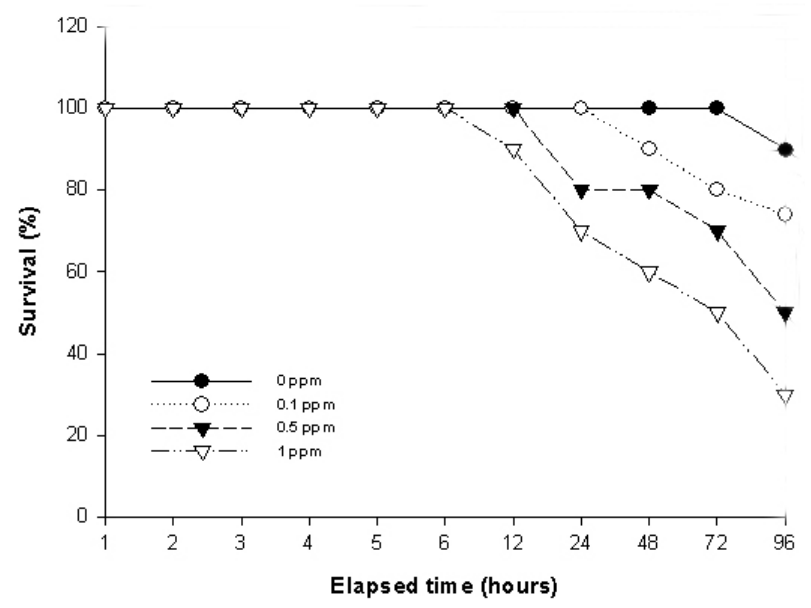

Fig. 1. Effect of $\mathrm{Cd}$ concentrations on survival of Carassius auratus.

흡수가 분당 0.025 가 되도록 조절하였다. 효소의 활성은 cytochrome C의 환원 속도를 $50 \%$ 억제하는 양을 1 unit로 하여 unit/mg protein으로 나타냈다.

\section{Catalase (CAT)}

CAT 활성은 $50 \mathrm{mM}$ phosphate buffer (pH 7.0)와 시료액을 넣은 후 기질로 $10 \mathrm{mM} \mathrm{H}_{2} \mathrm{O}_{2}$ 용액을 가하여 잘 혼합한 후 $240 \mathrm{~nm}$ 에서 흡광도의 변화를 2분간 측정하였다[1]. 대조실험 으로는 기질인 $\mathrm{H}_{2} \mathrm{O}_{2}$ 용액 대신에 $50 \mathrm{mM}$ phosphate buffer $(\mathrm{pH}$ 7.0)을 가하고 위와 동일한 방법으로 흡광도의 변화를 측 정하였다. CAT의 활성은 1 분 동안에 $1 \mu \mathrm{mol}$ 의 $\mathrm{H}_{2} \mathrm{O}_{2}$ 를 분해하 는 효소의 양을 1 unit로 하였다.

\section{Glutathione peroxidase (GPX)}

GPX 활성은 $1 \mathrm{mM}$ EDTA가 함유된 $100 \mathrm{mM}$ phosphate buffer (pH 7.6)에 $0.25 \mathrm{mM} \mathrm{GSH}, 0.12 \mathrm{mM} \mathrm{NADPH}, 20 \mathrm{mM}$ glutathione reductase $0.72 \mathrm{U}$ 가 포함된 반응액을 제조하였다 [12]. 이 반응액에 효소 시료액을 혼합한 후 $37^{\circ} \mathrm{C}$ 에서 5 분간 방치한 다음 $4 \mathrm{mM}$ cumene hydroperoxide를 첨가하여 340 $\mathrm{nm}$ 에서 1 분간 흡광도의 변화를 측정하였다. GPX의 활성은 1 분 동안에 $1 \mu \mathrm{mol}$ 의 $\mathrm{NADPH}$ 를 NADP로 산화하는 효소의 양을 1 unit로 하였다.

\section{조직학적 변화 관찰}

\section{광학현미경 관찰}

아가미와 신장 조직은 FAA로 24 시간 고정하였으며, 수세 와 탈수 과정을 거친 후 일반적인 조직 제작 방법에 따라 조직 을 paraffin 포매하였다. 이 후 paraffin block을 두께 4 6 $4 \mathrm{~m}$ 로 제작하여 hematoxylin과 eosin에 이중염색한 후, 광학현미경 하에서 관찰하였으며 Olympus DP-71을 사용하여 사진 촬영 을 하였다. 


\section{투과전자현미경 관찰}

아가미 조직을 절취하여 glutaraldehyde에서 전고정 후, osmium tetraoxide로 1시간 30분간 후고정 하였으며, ethyl alcohol을 사용하여 계대 탈수과정을 하였다. 탈수과정 후 propylene oxide로 치환하였으며, epon resin에 포매하여 $60^{\circ} \mathrm{C}$ 배양기에서 48 시간 중합하여 block을 제작하였다. 이 후 초미세절편기(Ultracut UCT, Leica)을 이용하여 $80 \mathrm{~nm}$ 로 박절 한 후 uranyl acetate와 lead nitrate로 이중 염색하여 투과전자 현미경(H-7000, Hitachi)을 이용하여 미세구조를 관찰한다.

\section{통계처리}

각 실험에서 얻어진 자료에 대하여 통계 프로그램 패키지 (SPSS Inc., ver 12.0K)를 이용하여 분석한 후, ANOVA test를 사용하여 평균값들 간의 유의성을 검정하였으며 $(\mathrm{p}<0.05)$, 모 든 데이터는 평균 \pm 표준편차 $(m e a n \pm S D)$ 로 표시하였다.

\section{결 과}

\section{조직 내 $\mathrm{Cd}$ 의 함량}

$\mathrm{Cd}$ 을 처리한 실험군의 붕어 조직 내 $\mathrm{Cd}$ 의 함량은 모든 조 직에서 노출기간이 길어질수록 $\mathrm{Cd}$ 의 함량이 증가하였으며, 노출 20 일에 가장 높은 함량을 보였다. $\mathrm{Cd}$ 의 함량이 가장 높은 조직은 아가미 조직으로 노출 20 일에 $40.94 \pm 2.05 \mathrm{ug} / \mathrm{g}$ 으로 대 조군에 비해 215배 함량이 높았다. 아가미 조직에서 $\mathrm{Cd}$ 의 함 량은 다른 뼈와 근육조직에 비해 노출 5 일부터 높은 함량을 보였다. 또한 뼈 조직과 근육 조직은 대조군에 비하여 노출 5 일에는 함량의 변화가 크지 않았으나 노출 20 일에는 대조군 과 비교 시 높은 함량의 차이를 보였다. 빼 조직은 노출 20 일에 $6.62 \pm 0.02 \mathrm{ug} / \mathrm{g}$ 으로 대조군에 비해 165 배의 높은 함량의 차이 를 보였으며, 근육 조직에서는 노출 20일에 $2.21 \pm 0.02 \mathrm{ug} / \mathrm{g}$ 으 로 대조군 보다 100 배의 함량 증가를 보였다. 따라서 $\mathrm{Cd}$ 을 처리한 실험군의 붕어 조직 내 $\mathrm{Cd}$ 의 축적량은 대조군과 비교
시 아가미 조직에서 가장 함량이 높았으며, 근육 조직에서 가 장 낮은 함량을 보였다(Fig. 2).

\section{조직 내 항산화효소의 활성 변화}

$\mathrm{Cd}$ 을 처리한 실험군의 붕어 조직 내 항산화효소의 활성은 모든 조직에서 노출 5 일부터 증가하기 시작하여 노출 10 일에 가장 높은 활성을 보인 후 노출 20일에 감소하는 경향을 보였 다. 아가미, 근육 및 신장 조직의 $\mathrm{SOD}$ 의 활성은 노출 기간이 길어질수록 증가하여 노출 10 일에 가장 높은 활성을 보인 후 감소하는 경향을 보였으나, 간 조직에서는 노출 기간이 길어 질수록 활성이 증가하여 노출 20 일에 가장 높은 활성을 보였 다. $\mathrm{SOD}$ 의 활성 중 가장 높은 활성은 아가미 조직으로 노출 10 일에 $55.00 \pm 9.12 \mathrm{unit} / \mathrm{mg}$ protein의 활성을 보였으며, 신장 조직이 가장 낮은 활성을 보였다. 또한 대조군의 활성과 비교 시 가장 높은 활성의 차이를 보인 조직은 간 조직으로 노출 20 일에 $48.36 \pm 5.51 \mathrm{unit} / \mathrm{mg}$ protein으로 3.6배의 활성 차이를 보였다. 모든 조직에서 CAT의 활성은 노출 10 일에 가장 높은 활성을 보인 후 노출 20 일에 감소하였다. 가장 높은 활성을 보인 근육 조직은 노출 10 일에 $33.90 \pm 1.44 \mathrm{unit} / \mathrm{mg}$ protein을 보였으며, 신장 조직이 가장 낮은 활성을 보였다. 또한 대조군 과 비교 시 가장 높은 활성의 차이를 보인 조직은 아가미 조직 으로 노출 5 일에 $23.32 \pm 4.88 \mathrm{unit} / \mathrm{mg}$ protein으로 대조군의 활성에 비해 2.2배의 활성 차이를 보였다. GPX의 활성은 간 조직을 제외하고 노출 기간이 길어질수록 증가하는 경향을 보였으나, 노출 20 일에 다시 감소하였다. GPX의 활성이 가장 높은 조직은 아가미 조직으로 노출 10 일에 $15.52 \pm 0.54$ unit/mg protein의 활성을 보였으며, 간 조직이 가장 낮은 활 성을 보였다. 대조군과 비교 시 활성의 차이가 가장 큰 조직은 근육 조직으로 노출 후 20일에 $7.42 \pm 1.63 \mathrm{unit} / \mathrm{mg}$ protein으로 대조군의 활성에 비해 6 배의 활성 차이를 보였다. 따라서 항산 화효소의 활성은 아가미와 근육 조직에서 활성이 높았으며, 신장과 간 조직에서 활성이 낮았다. 그러나 대조군과 비교 시
A

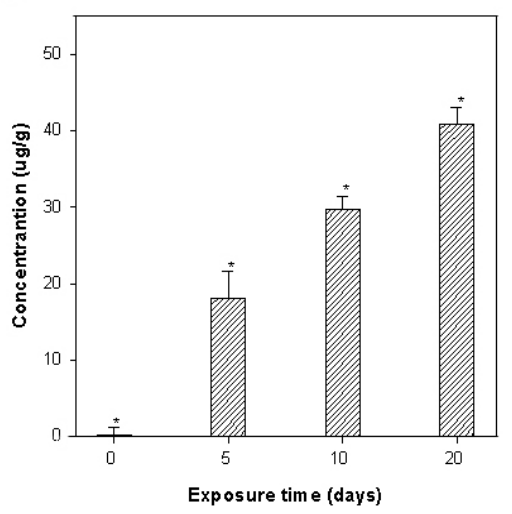

B

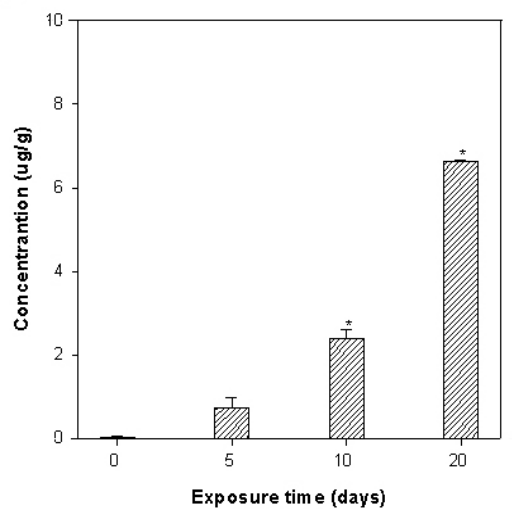

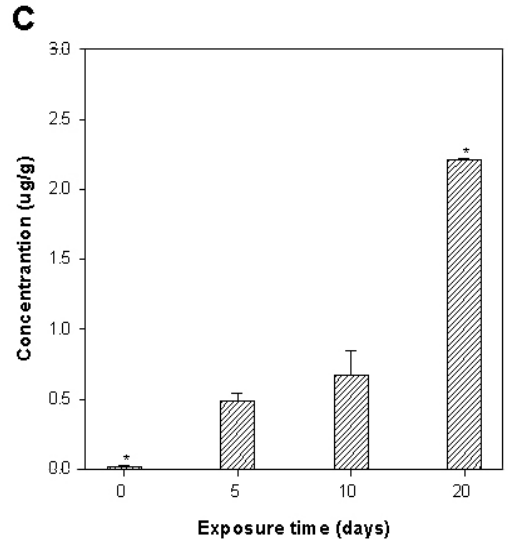

Fig. 2. Contents of $\mathrm{Cd}$ of $\mathrm{C}$. auratus tissues during 20 days exposed to $\mathrm{Cd} 0.3 \mathrm{mg} / \mathrm{l}$ in water. A: gill, B: bone, C: integument. The values are mean $\pm S D(n=5) . p<0.05$ (Significantly different from control and $C d 0.3 \mathrm{mg} / 1$ treated group) 

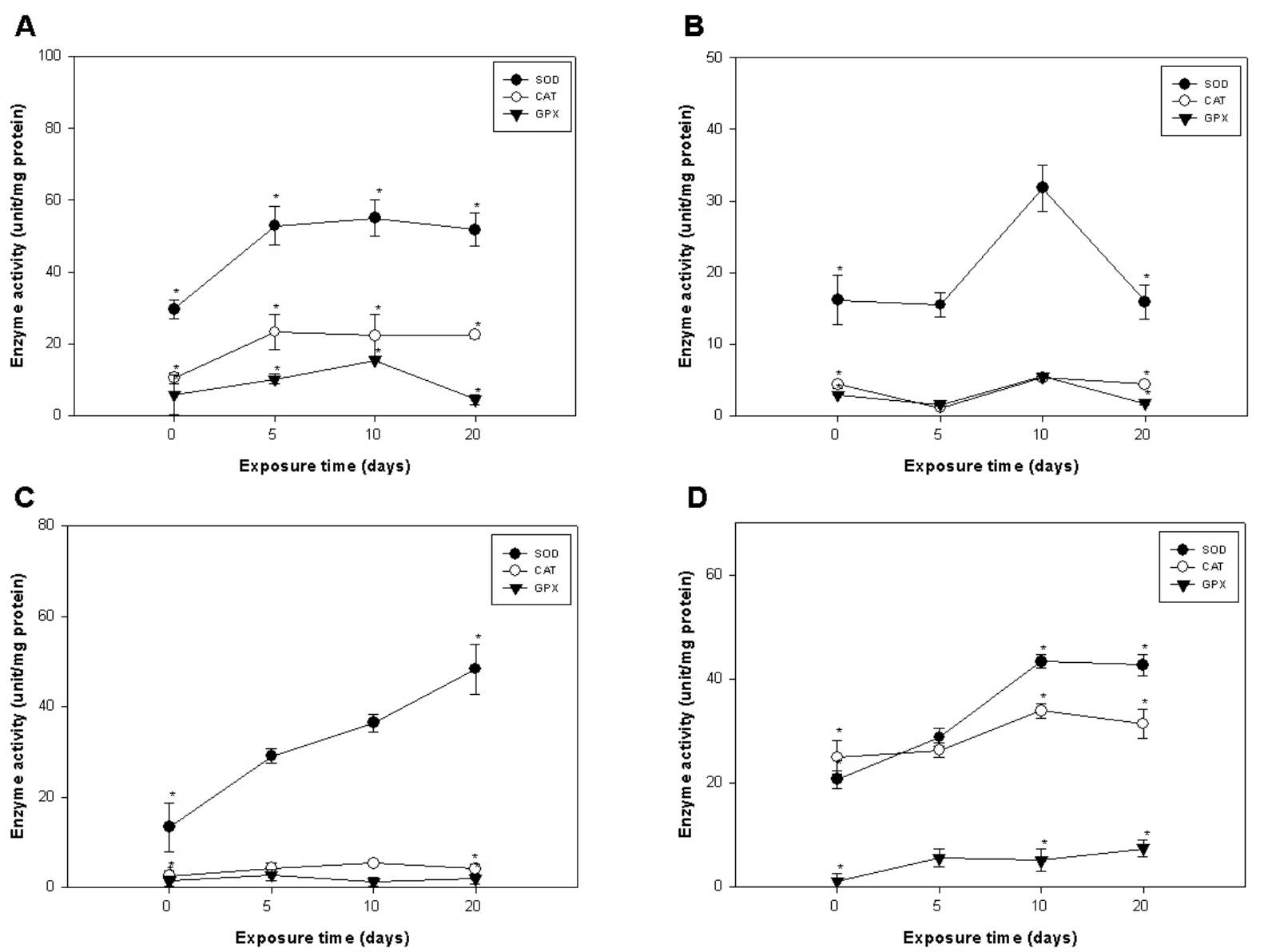

Fig. 3. Various antioxidant enzyme activities of C. auratus tissues during 20 days exposed to $\mathrm{Cd} 0.3 \mathrm{mg} / 1 \mathrm{in}$ water. A: gill, B: kidney, C: liver, D: integument. The values are mean \pm SD (n=5). $p<0.05$ (Significantly different from control and Cd 0.3 $\mathrm{mg} / \mathrm{l}$ treated group)

활성의 차이는 아가미와 근육 조직 보다 신장과 간 조직에서 높은 활성의 차이를 보였다(Fig. 3).

\section{아가미와 신장의 조직 변화}

대조군 아가미 조직은 이차새변 사이의 공간이 비교적 일정 하였고 새변사이의 점액세포 수의 증가도 관찰되지 않았다. $\mathrm{Cd}$ 을 5 일간 처리한 실험군 붕어의 아가미 조직은 이차새변 사이의 공간이 비교적 일정하였으나 점액세포 수가 증가하기 시작하였으며 10 일에는 상피세포의 비대와 곤봉화가 나타나 기 시작하였다. 노출 20 일에는 점액세포 수의 증가와 곤봉화 가 두드러지게 관찰되었으며, 새변과 새변이 접하여 융합한 형태도 관찰되었다(Fig. 4). 투과전자현미경을 통한 아가미 조 직의 형태적 변화에서는 대조군 아가미 조직의 세포 소기관인 미토콘드리아 및 핵에서 막의 손상 없이 정상적인 형태로 관 찰되었다. 그러나 $\mathrm{Cd}$ 에 20 일간 처리한 실험군의 아가미 조직 은 세포소기관인 미토콘드리아와 핵에서 막이 손상되었다 (Fig. 5). 대조군의 신장 조직은 보우만 주머니 안에 사구체가 가득 차 있는 정상적인 구조로 관찰되었고 노출 5 일에서도
정상적인 구조를 보였다. 그러나 10 일과 20 일로 노출기간이 길어짐에 따라 사구체의 수축이 점점 증가하여 보우만 주머니 안의 공간이 넓게 관찰되었다(Fig. 6).

\section{고 찰}

우리 주변에 존재하는 독성물질의 종류가 다양하고, 많은 혼합물에 대한 독성학적 자료의 결핍, 또 이들 혼합물의 감지 와 분석의 어려움, 그들 상호작용에 대한 영향 예측의 어려움 등의 이유로 인해 이화학적 분석만으로는 생물체에 작용하는 수질의 독성을 평가하는데 한계가 있다[9]. 생물검정은 수계에 존재하는 잠재적인 독성여부를 결정하는데 많은 도움을 줄 수 있으며, 화학적 분석방법의 보완방법으로 사용될 수 있다 [8]. 또한 중금속은 철, 구리 등과 같은 생체 내 필수 원소도 있지만 납, 수은 및 카드뮴과 같은 유해금속들도 있으며 이들 대부분은 생체 내에서 다양한 유해작용을 유발하게 된다[16]. 따라서 본 연구에서는 $\mathrm{Cd} 0.3 \mathrm{mg} / 1$ 을 처리한 실험군 붕어를 이용하여 중금속의 축적정도와 이에 따른 아가미와 신장 조직 

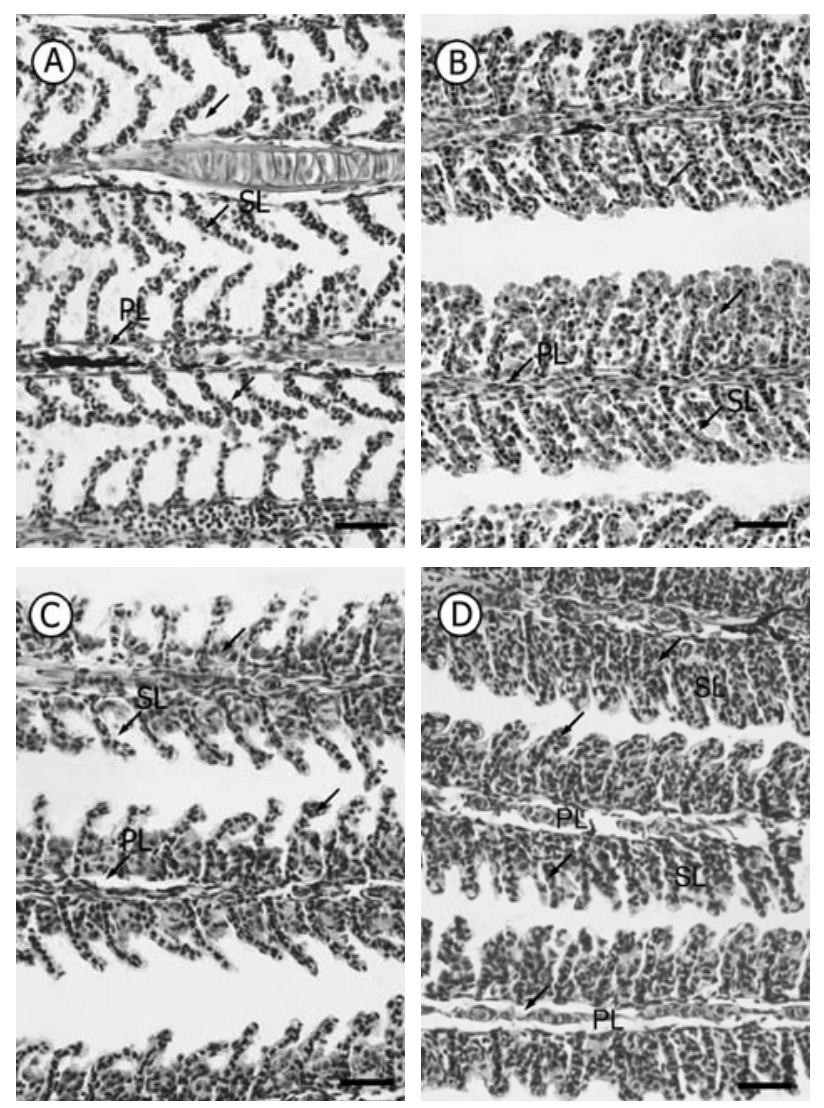

Fig. 4. Micrographs of C. auratus gill during 20 days exposed to $\mathrm{Cd} 0.3 \mathrm{mg} / 1$ in water. A: Exposed to water for 0 day, B: Exposed to $\mathrm{Cd} 0.3 \mathrm{mg} / \mathrm{l}$ for 5 days, C: Exposed to $\mathrm{Cd} 0.3 \mathrm{mg} / 1$ for 10 days, D: Exposed to Cd $0.3 \mathrm{mg} / 1$ for 20 days. Scale bar: A, B, C, D=50 $\mu \mathrm{m}$. PL: primary lamella, SL: secondary lamella.

에서 미세구조의 변화와 중금속 함량 및 항산화효소의 활성을 통해 생리적인 변화를 알아보고자 하였다.

중금속을 비롯한 유해물질은 비록 미량일지라도 수생생물 에 농축, 축적이 가능하며 먹이연쇄를 통해 인체에까지 영향 을 미치게 되므로 중금속에 의한 수서생물의 오염은 사람의 공중보건에 직결되는 심각한 문제가 되기도 한다[13]. 송사리
(Oryzias latipes)의 생체 내 카드뮴 및 미량금속의 축적에 관한 실험적 연구로 $\mathrm{Cd}$ 농도를 $0.03 \mathrm{ppm}$ 으로 8 주간의 노출실험을 한 결과 $\mathrm{Cd}$ 의 농도는 1 주에 $4.85 \pm 1.86 \mathrm{ug} / \mathrm{g}, 4$ 주 $6.32 \pm 2.70$ $\mathrm{ug} / \mathrm{g}, 8$ 주에서 $7.14 \pm 2.60 \mathrm{ug} / \mathrm{g}$ 으로 $\mathrm{Cd}$ 에 노출되는 시간이 길 어짐에 따라 지속적인 축적현상을 확인하였다[19]. 또한 Cho 와 $\mathrm{Kim}[6]$ 은 진주담치와 넙치를 치사 농도 이하의 $\mathrm{Cd}$ 을 첨가 한 배양 수조에 2 주간 노출시킨 후 생물체내 중금속 농도를 조사한 결과 고농도의 배양액에 노출시킨 시료에서 최대치를 나타냈다. 또한 $\mathrm{Cd} 1.0 \mathrm{mg} / 1$ 배양액에서 넙치와 담치의 $\mathrm{Cd}$ 최대농도는 각각 $72( \pm 4) \mathrm{ug} / \mathrm{g}, 1040( \pm 4) \mathrm{ug} / \mathrm{g}$ 으로 $\mathrm{Cd}$ 의 생물 축적이 배양액 농도와 직접 관련이 있음을 보고하였다. 본 연 구에서도 노출기간이 길어질수록 $\mathrm{Cd}$ 의 함량이 증가하여 $\mathrm{Cho}$ 와 Kim [6]과 Park 등[19]의 보고에서 Cd의 함량이 미량일지 라도 노출기간이 길어짐에 따라 증가한다는 결과와 유사하였 다. 또한 이러한 결과는 중금속의 함량이 미량일지라도 장시 간 노출이 되면 어류에 체내에 지속적인 축적이 일어나며 이 러한 축적은 어류 조직에서 미세구조의 변화와 생리적 병변을 나타낼 것으로 생각된다.

일반적으로 유해중금속이 생체 내에 흡수되었을 경우 독성 학적 방어기전으로는 중금속에 노출된 각 표적장기 세포에서 지질과산화반응(lipid peroxidation)을 통해 유리된 활성산소 의 공격에 대해 superoxide dismutase나 catalase와 같은 scavenger를 유도하여 방어하기도 하고[23], 중금속에 특이적으로 결합하는 물질들의 합성을 촉진하거나[24] 새로운 대사물로 전환시킴으로써 세포에 미치는 독성을 경감시킨다[20]. 또한 어류는 심한 스트레스를 받게 되면 여러 산화성 물질 중 다량 의 활성산소를 발생하게 된다[4]. 이러한 활성산소는 생체 내 에서 다른 물질과 결합하려는 화학적 친화력이 강해서 세포나 기관의 막을 공격하여 세포의 기능을 손상시켜 생존에 커다란 위협이 된다. 또한 어류는 이러한 활성산소를 여러 종류의 비 효소성 항산화제와 효소성인 항산화효소의 작용을 통해 제거 함으로서 세포의 기능손상을 막게 된다[4,25]. 본 연구의 $\mathrm{Cd}$ $0.3 \mathrm{mg} / 1$ 에 처리한 실험군 붕어의 경우 아가미, 신장, 근육 조직에서 $\mathrm{SOD}$ 활성은 노출초기에 증가하며 노출후기인 20 일 에 활성이 감소하는 경향을 보였다. 신장 조직에서 CAT의 활
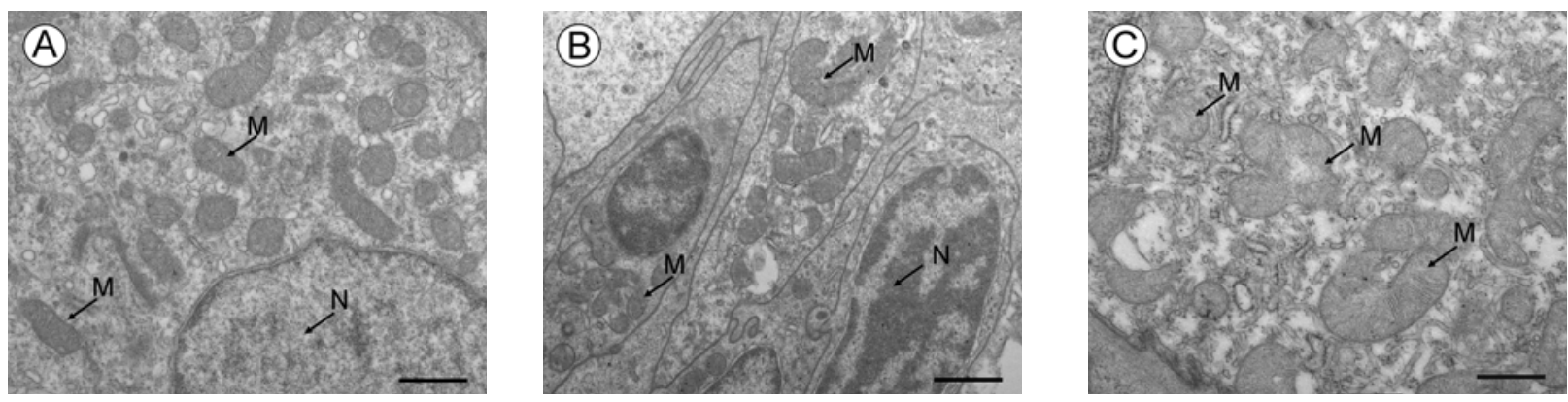

Fig. 5. Transmission electron microscope of C. auratus gills during 20 days exposed to $\mathrm{Cd} 0.3 \mathrm{mg} / \mathrm{l}$ in water. A: Exposed to water for 0 day. B, C: Exposed to Cd $0.3 \mathrm{mg} / 1$ for 20 days. Scale bar: A, B, C=2 $\mu \mathrm{m}$. M: Mitochondria, N: Nucleus. 

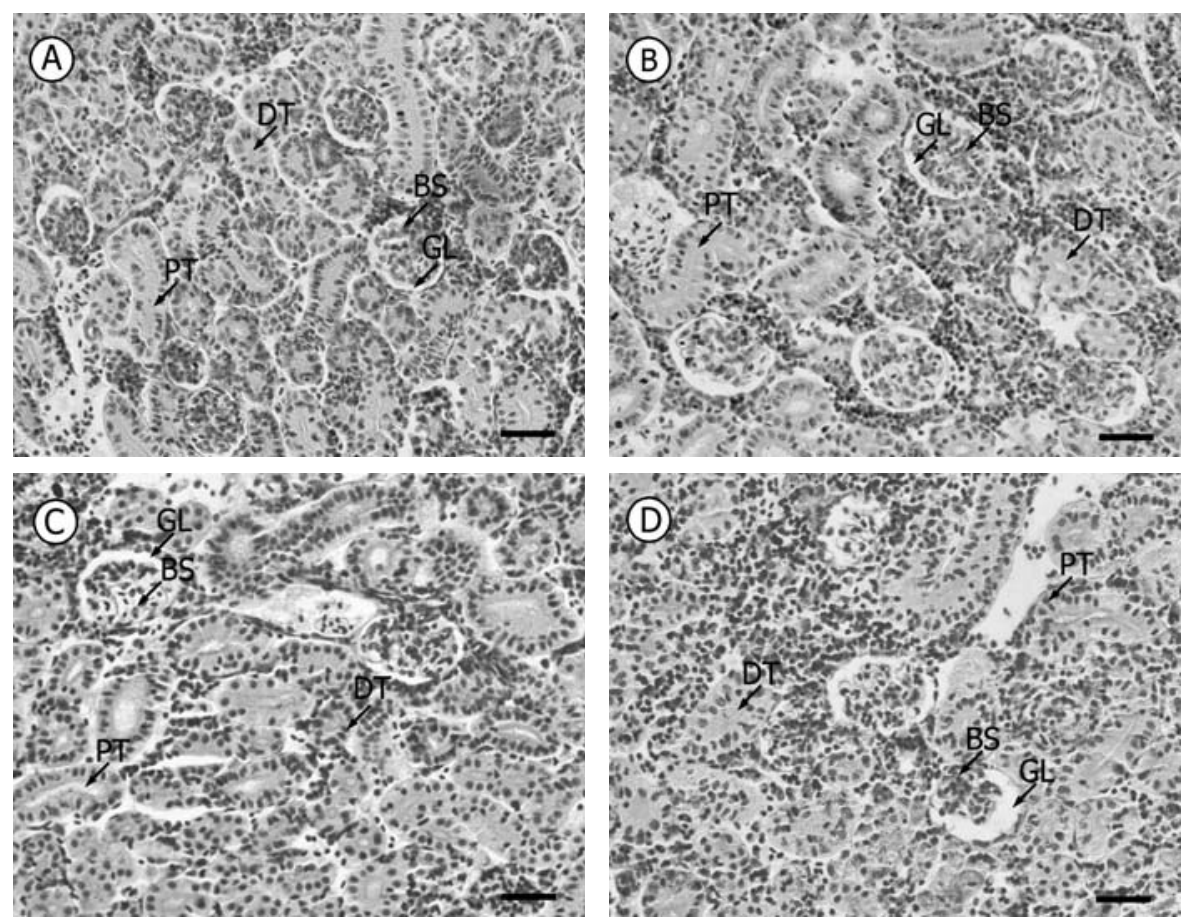

Fig. 6. Micrographs of $C$. auratus kidney during 20 days exposed to $\mathrm{Cd} 0.3 \mathrm{mg} / 1$ in water. A: Exposed to water for 0 day, B: Exposed to $\mathrm{Cd} 0.3 \mathrm{mg} / 1$ for 5 days, C: Exposed to Cd $0.3 \mathrm{mg} / 1$ for 10 days, D: Exposed to Cd $0.3 \mathrm{mg} / 1$ for 20 days. Scale bar: A, B, C, D=50 $\mu \mathrm{m}$. BS: Bowman's space, DT: Distal tubule, GL: Glomerulus, PT: Proximal tubule.

성은 대조군과 유사하였으며 다른 조직에서의 활성은 노출초 기에 증가하였다가 노출후기인 20일에 감소하는 경향을 보였 다. 이러한 결과로 보아 $\mathrm{Cd}$ 에 노출시킨 환경적 스트레스에 대해 환경변화초기에는 $\mathrm{SOD}$ 와 $\mathrm{CAT}$ 와 같은 항산화효소에 의 한 항산화작용이 주로 이루어지나 장시간 노출이 되면 어느 정도 환경적 변화요인에 적응해 가는 것으로 사료된다.

독성물질에 대한 아가미 조직의 반응은 두 그룹으로 나눌 수 있는데 그 하나는 독성물질이 아가미를 통하여 흡수되는 것을 막거나 그 독성작용을 감소시키기 위한 변화이다. 상피 세포의 비후, 비대, 점액세포의 증식 등은 아가미 모세혈관과 환경수와의 거리를 증가시켜 독성물질이 아가미로 확산되어 들어가는 것을 막기 위한 반응이고, 독성물질의 배출을 위한 변화로 염세포가 비대, 증식되는 현상이 나타날 수도 있다. 그러나 독성물질로 인하여 계속 자극받아 이러한 반응이 계속 진행되면 아가미 이차새엽의 두께가 점점 두꺼워져 산소의 흡수가 어려워지므로 질식으로 인하여 어류 호흡곤란을 가져 와 어류의 치사가 나타날 수 있다. 또 하나는 독성물질에 의해 직접 받는 독성작용으로서 상피세포의 괴사, 탈락, 상피층의 박리 등이 여기에 속한다[18]. 또한 $\mathrm{Cd}$ 의 축적에 따른 붕어의 아가미 조직에서는 새판 상피층의 비후, 새판 말단부의 미약 한 곤봉화 및 모세혈관의 확장과 혈구의 증가, 새엽 및 새판 상피층의 비후, 새판의 만곡 및 곤봉화 현상의 진행, 새판 및 새엽 상피층의 박리가 순차적으로 관찰되었다[3]. 본 연구에서
$\mathrm{Cd}$ 을 처리한 실험군 붕어에서 관찰된 아가미 조직은 노출기 간이 길어질수록 이차 새엽의 두께가 점점 두꺼워졌으며 점액 세포 수의 증가와 곤봉화 형태가 두드러지게 나타났다. 이러 한 병변들은 보편적으로 나타나는 어류 아가미 조직에서의 병리조직학적 변화로 독성물질에 대한 아가미의 조직학적 변 화로 생각된다. 또한 어류의 아가미와 더불어 신장도 수질오 염과 같은 환경적 스트레스에 의해서 사구체 수축의 구조적 변형을 나타내는데 사구체의 수축은 포유류의 만성 사구체 신염과 유사한 병변으로 어류의 경우에도 2 차 병변의 원인이 될 수 있다[11]. 본 연구에서는 노출초기에는 사구체의 수축이 두드러지지 않았으나 노출후기에 두드러진 것으로 보아 장기 간 $\mathrm{Cd}$ 에 노출될 경우 사구체의 수축이 증가함으로써 신장 조 직의 구조적 변형에 따른 어류의 2 차 병변을 나타낼 것으로 사료된다.

\section{References}

1. Aebi, H. 1984. Catalase in vitro, pp. 121-126, In Packer, L. (ed.), Methods in Enzymology, 105, Academic Press Inc., New York.

2. APHA-AWWA-WPCF. 1985. Standard methods for the examination of water and wastewater. pp. 715-742. 16th eds., Washington, D. C.

3. Bae, H. K., E. K. Kim, S. S. Nam, C. K. Moon, S. H. Jeon, 
J. G. Na, and K. S. Park. 2002. A study on cadmium accumulations and histopathological changes in the gills of Crucian Carp (Carassius auratus). Korean J. Environ. Toxicol. 17, 53-61.

4. Chance, B., H. Siec, and A. Boveris. 1979. Hydroperoxide metabolism in mammalian organs. Physiol. Rev. 59, 527-605.

5. Cho, K. S., J. H. Park, and J. C. Kang. 2004. Acute toxicity of Carassius auratus and Pungtungia herzi lavra on mercury, lead and copper exposure. J. Korean Soc. on Water Quality 20, 265-268.

6. Cho, Y. G. and G. B. Kim. 2007. Bioaccumulation of Pb and $\mathrm{Cd}$ in Blue mussel (Mytilus edulis) and Oliver flounder (Paralichthys olivaceus) exposed to rearing media. J. Korean Soc. for Marine Eviron. Eng. 10, 21-28.

7. Dudkey, R. E., D. J. Sovovoda, and C. D. Klaassen. 1982. Acute exposure to cadmium causes servere liver injury in rats. Toxicol. Appl. Pharmacol. 65, 302-313.

8. EPA. 1978. Criteria and rationale for decision making in aquatic hazard evalution, aquatic hazard of pesticides task group, Amer. Inst. Biol. Science, pp. 46, Arlinton, Virginia.

9. EPA. 1989. Short-term method for estimating the chronic toxicity of effluent and receiving water to freshwater organism, U.S. EPA-600/4-89-001.

10. Faeder, E. J., S. Q. Chanet, and L. C. King. 1977. Biochemical and ultrastructural changes in livers of cadmium treated rats. Toxicol. Appl. Pharmacol. 39, 473-483.

11. Fennel, R. H. and V. M. Pardo. 1967. Experimental glomerulonephritis in rats. Lab. Invest. 17, 483-488.

12. Flohe, L., A. Wolfgang, and W. A. Gunzler. 1984. Assay of glutathione peroxidase, pp. 105-114, In Packer, L. (ed.), Methods in enzymatic analysis, Academic Press Inc., New York.

13. Friberg, L. and J. Vostal. 1972. Mercury in the environment, pp. 17-23, CRS Press Inc., Cleveland.

14. Goyer, R. A. 1986. Toxic effect of metals. Casarett and Doull's Toxicology, pp. 623-680, In Klaassen, C. D., M. D. Amder, and J. Doull (eds.), Mecmillian Publishing Co., New York.

15. Kim, J. S., M. J. Shin, J. E. Lee, and E. W. Seo. 2009. Heavy metal contents in tissues of Carassius auratus in Andong and Imha reservoir. J. Life Sci. 19, 1562-1567.

16. Lee, J. S., J. C. Kang, and Y. K. Shin. 2001. Histological responses of the flounder, Paralichthys olivaceus exposed to copper. J. Fish Pathol. 14, 81-90.

17. McCord, J. M. and I. Fridovich. 1969. Superoxide dismutase an enzymic function ferythrocuprotein (Hemocuprotein). J. Biol. Chem. 244, 6049-6055.

18. Muller, M. E., D. A. Sanchez, H. L. Bergman, D. G. Rhem, and C. M. Wood. 1991. Nature and time course of acclimation to aluminium in juvenile brook trout (Salvelinus fontinalis). Gill histology. Can. J. Fish Sci. 48, 2016-2027.

19. Park, S. H., I. S. Song, and Y. C. Cho. 2000. Experimental study on the accumulation of cadmium and other metals in the fish bodies (Oryzias latipes). Korean J. Environ. Hlth. Soc. 26, 25-31.

20. Probes, G. S., W. F. Bousquet, and T. S. Miya. 1977. Kinetics of cadmium-induced hepatic and renal metallothionein synthesis in the mouse. Toxicol. Appl. Pharmacol. 39, 51-60.

21. Schmitt, C. J. and G. M. Dethloff. 2000. Biomonitoring of environmental status and trends (BEST) program, selected methods for monitoring chemical contaminants and their effects in aquatic ecosystems. U. S. Geological Survey, Biological Resources Division, Information and Technology Report, USGS/ BRD/ITR-2000-0005.

22. Sorensen, E. M. 1991. Cadmium. In: Metal Poisoning in Fish. pp. 175-234, CRC press Inc., Boston.

23. Stacey, N. H. and C, D. Klaassen. 1981. Comparison of the effects of metals on cellular injury and lipid peroxidation in isolated rat hepatocyte. J. Toxicol. Environ. Hlth. 7, 139.

24. Webb, M. and A. T. Etienne. 1977. Studies on the toxicity and metabolism of cadmium thionein. Biochem. Pharmacol. 26, 25-30.

25. Wendel, A. and S. Feuerstin. 1981. Drug-induced lipid peroxidation in mice-l. Modulation by monoxygenase activity, glutathione and selsnium status. Biochem. Pharmacol. 30, 2513-2520. 


\section{초록 : 카드뮴 노출이 붕어(Carassius auratus) 조직에 미치는 영향}

신명자 · 권오창 · 이종은 · 서을원*

(안동대학교 자연과학대학 생명과학과)

본 연구는 $\mathrm{Cd}$ 에 노출시킨 붕어를 통하여 각 조직에 축적된 $\mathrm{Cd}$ 양과 항산화효소 활성을 통해 생리적인 변화 및 아가미와 신장 조직에서의 미세구조 변화를 조사하였다. $\mathrm{Cd}$ 을 처리한 실험군 붕어 조직 내 $\mathrm{Cd}$ 의 함량은 아가 미 조직에서 가장 높았고 근육 조직에서 가장 낮았다. 또한 모든 조직에서 $\mathrm{Cd}$ 의 함량은 노출기간이 길어질수록 증가하여 노출 20 일에 가장 높았다. 항산화효소의 활성은 아가미와 근육 조직에서 높았으며, 신장과 간 조직에서 낮았다. 모든 조직에서 $\mathrm{SOD}$ 의 활성이 가장 높았으며, $\mathrm{SOD}$ 와 $\mathrm{CAT}$ 의 활성은 10 일에 높은 활성을 보이고 감소하 는 유사한 결과를 보였다. $\mathrm{Cd}$ 에 20 일간 노출시킨 붕어의 아가미 조직은 대조군 아가미 조직에 비하여 노출기간 이 길어질수록 새변 사이에 점액세포의 수가 증가하였으며, 이차새변에서는 부종, 상피세포의 박리와 새변과 새 변이 융합한 형태도 관찰되었다. 또한 아가미 조직의 미토콘드리아와 핵에서는 막의 손상이 확인되었다. 신장 조직은 대조군에서 보우만 주머니 안에 사구체가 꽉 찬 정상구조였으나 노출기간이 길어짐에 따라 사구체가 수 축하여 보우만 주머니 안의 공간이 넓은 형태로 관찰되었다. 